\title{
The Problems of Development of Economic Institutions in Russia
}

\author{
Zhanna Mingaleva $^{1} \&$ Andrey Shelomentsev ${ }^{2}$ \\ ${ }^{1}$ Perm National Research Polytechnic University, 29, Komsomolsky Av., Perm, Russian Federation \\ ${ }^{2}$ Vladivostok State University of Economics and Service, 41, Gogolev str., Vladivostok, Russian Federation \\ Correspondence: Zhanna Mingaleva, Perm National Research Polytechnic University, 29, Komsomolsky Av., \\ Perm, Russian Federation. E-mail: mingal1@pstu.ru
}

Received: June 28, 2014 Accepted: July 23, 2014 Online Published: September 28, 2014

doi:10.5539/ass.v10n20p210 URL: http://dx.doi.org/10.5539/ass.v10n20p210

\begin{abstract}
Delayed payments of wages, defaults, hostile takeovers of privatized companies and similar actions caused a lot of problems in economic system of Russia. Notwithstanding the every effort taken by the government, the new model of economic management was inefficient until a cluster of complementary institutions was formed. Analysis of transformation processes in the Russian economy shows that the evolution of economic institutions has since the early 90 s been a complicated, often inconsistent process, mainly directed towards internalization of informal institutions, import of institutions and restoration of institutions.

The paper examines the evolution of economic institutions in Russia since the beginning of market reforms. The authors reveled the close relationship and direct correlation between the effectiveness of Russian economic reforms and forming the new economic institutions.
\end{abstract}

Keywords: economic institutions, economic development, reestablishment, internalization of informal institutions, import of institutions, restoration of institutions

\section{Introduction}

Over the last twenty years, like in other former socialist countries the import of economic institutions into the real sector of the Russian economy has been heavy and had the most severe consequences.

Since the early 1990s, the institutional principles of domestic economy in Russia have undergone revolutionary change. However, the processes ran quite spontaneously. Thus the pre-existing economic ties severed, which led to coercive (noneconomic) demolishing of the once established "rules", consequently creating chaos in the national economy. The government was unable to propose any viable alternative, leaving reconstruction of the ruined-by-reform institutions to their spontaneous reestablishment on the new ideology base. In the long run the existent economic processes may result in various changes in the economic systems, including functional modifications of the existing economic institutions, with the old institutions withering away and new ones emerging. That depends on entrepreneurs' awareness of the change and of the depth in the actual contradictions. As this occurs, awareness and will are realized via economic interests, which generally constitute the basics of the mechanism for functioning and reformation of economic systems.

\section{Theoretical and Methodological Background}

\subsection{The Theory}

The research is based on the foreign and Russian researchers' theoretical theses in the fields of the institutional theory (Ben-Ner \& Putterman, 2000; Engerman \& Sokoloff, 2008; Chang, 2007). The problems of anomie and institutional vacuum were discussed by Émile Durkheim (Durkheim, 1993). The fundamental approaches to the analysis of institutions are contained in the research of J. Aron (2000), G. Caravale (1995), G. Hodgson (2009), D. North (1990, 1995), E. Ostrom (1990, 2007), S. Pejovich (1972) and others (Bergstrom, 2002; Chakravarti, 2012).

The questions of neo-liberal theory in institutionalist political economy are analyzed by H. J. Chang (Chang, 2002), M. Cimoli, G. Dosi and J. Stiglitz (Cimoli, Dosi, \& Stiglitz, 2009) and others.

The overview of evolutionary theories of institutions in biology, sociology, anthropology and economics made in the works by J. C. J. M. Van den Bergh (Vrije University Amsterdam, Faculty of Economics and 
Business Administration and Institute for Environmental Studies, Amsterdam, Netherlands) and S. Stagl (School of the Environment, University of Leeds, United Kingdom) (Van den Bergh \& Stagl, 2003). They compared the non-evolutionary theories of institutions and co-evolutionary theories of institutions and they developed the co-evolution approach for analysis of institutions.

The research of M. K. Nabli (World Bank, South Africa) and J. B. Nugent (University of Southern California, Los Angeles, United States) (Nabli \& Nugent, 1989) identifies the potential complementarities between the important components of new institutional economics and illustrates their applicability to various problems and policies in the long-term development of developing countries. This analysis is applicable to the assessment of the situation of development of economic institutions in Russia in the different areas of economy and society: the questions of innovation activities, of intellectual property protection, of economic security, of social integration (Mingaleva \& Mirskikh, 2009, 2013, 2014; Mingaleva \& Gataullina, 2012; Shelomentsev, 2007).

The issues of institutional role and its importance in the development of various countries and regions in the different areas have been actively discussed: the questions of public-private agreements, institutions, and competition (Che \& Qian, 1998; Gehlbach \& Keefer, 2011; Ostrom, 1990; Saussier, Staropoli, \& Yvrande-Billon, 2009; Spiller, 2008), of institutions and economic development (Chang, 2011; Dorward et al., 2003; Glaeser, La Porta, Lopez-de-Silanes, \& Shleifer, 2004; Ostrom, 2007), of institutional mechanism of region's innovative development (Mingaleva, Gayfutdinova, \& Podgornova, 2009), institutions and entrepreneurship (High, 2009; Holcombe, 1998, 2003), and other problems (Engerman \& Sokoloff, 2005; Spiller, 1996; Stein, 2008; Streeck, 1992; Udry, 2003). Special literature reviews are devoted to the coverage of most of these issues.

The research of A. Dorward, J. Kydd, J. Morrison and C. Poulton (2005) are strong historical, theoretical and practical grounds for more consistent policy in co-ordination functions at institutions in an economy.

The factor analysis of the rapid growth in newly industrializing countries (Korea, Taiwan, Hong Kong, and Singapore) of the East Asian was conducted by S. Haggard (University of California, San Diego, CA, United States) and Chung-In Moon at 1989. They researched the organizational factors and institutionalism arguments of economic efficiency. They concluded that unique institutional solutions for political problems and the indeterminacy of institutional configuration ought to be conducted with respect to the economic efficiency of policy limits of economic growth. The analysis of the importance of institutions for development of Asian countries has been made in the paper of H. J. Chang (Faculty of Economics, University of Cambridge) (1998). Prof. Chang identified three types of institutions that are particularly important for economic development: institutions for coordination and administration, institutions for learning and innovation, and institutions for income redistribution and social cohesion. He examined how they contributed to the development of different Asian countries. He concluded that the institutional changes need to be made cautiously and in line with local conditions.

In his works S. Haggard (University of California, San Diego, United States) examines the correlation between the institutions and economic growth in Taiwan. S. Haggard and Y. Zheng (University of Connecticut, United States) concluded that the rapid growth in the East Asian newly industrializing countries depended on institutional innovation (Haggard \& Zheng, 2013). The research of S. Haggard and T. J. Cheng (Department of Political Science, College of William and Mary, Williamsburg, VA, United States), and D. Kang (Government Department, Dartmouth College, Hanover, NH, United States) examined bureaucratic reform in Korea and Taiwan (Cheng, Haggard, \& Kang, 1998). The authors analyzed the political and institutional constrains under which governing elites operate and they concluded that in both countries political leaders had an interest in reforming the civil service to carry out their initiatives at the institutional base. The institutional changes stimulate economic development of countries with the authoritarian governments.

H. Stein at Roosevelt University in Chicago critically examines the theories of institutions that can be used as a guide to economic reform in Africa, primarily the development of markets in Africa (Stein, 1994). He analyzes three approaches to institutions: the old institutionalism tradition, new institutional economics and the model of structural adjustment. And he concluded that the recommendations of structural adjustment and new institutional economics do not promote the development of markets in Africa. He recommended using the old institutionalism literature to promote market reform in Africa.

T. Kuran (2004) analyzed the historical mechanisms of institutional stagnation and the problems of economically underdeveloped in the Middle East.

Finally, most of the works of J. W. Eerkens (2004), E. Perotti (1995) and some others (Bortolotti, Siniscalco, \& Fantini, 2000) are devoted to the analysis of the issues of privatization and institutionalization. 
B. Bortolotti, D. Siniscalco (University of Turin), and M. Fantini (University of Bergamo) conducted the cross country analysis correlation between the privatisation and institutions (2000). From a sample of 49 developed and developing countries by an empirical analysis of the period 1977-96 (except Russia and all post-soviet countries) they proved that the scope of privatisation is determined by a variety of institutional, economic and political factors.

\subsection{The Methodology of Research}

The authors used the methods of institutional analysis, comparative analysis and historical analysis, the analysis of current situation, analysis of legislation. The methods of comparative analysis and historical analysis used to reveal the relationship and correlation between the effectiveness of Russian economic reforms and forming the new economic institutions. During the research process methods of bibliographic analysis and publication analysis were used. The paper presents complex interdisciplinary analysis of legal, economic, political aspects of evolution of economic institutions in Russia.

\section{The History of Development of Economic Institutions in Russia}

One would traditionally consider the following evolutionary forms of economic behavior patterns such as:

1) institutions of a certain ideal model are reduced to practice;

2) institutions reproduce patterns that existed earlier in the history of a given country but then disappeared due to some social and political changes;

3) formal institutions are constructed following patterns that exist in other countries.

Of the formal change frameworks mentioned above, the first two have such a trait that they may have common cultural and historical (genetic) roots with a specific society and with features characterizing its disposition and economic organization. The latter case, however, appears to address the application of foreign patterns, which are neither connected with the national cultural traditions, nor related to the customs of economic life in the given country. Moreover, by the experience gained in the political and economic transformations in the former socialist countries it has been demonstrated that the import of market institutions from other countries has independently disseminated and been the most widespread. Analysis of transformation processes in the Russian economy shows that the evolution of economic institutions has since the early 90 s been a complicated, often inconsistent process, mainly directed towards internalization of informal institutions, import of institutions and restoration of institutions.

Internalization of informal frameworks is one of the prevalent forms of the evolution of economic institutions. Depending on the relationship between formal and informal norms accepted within a specific time frame, internalization may either supplement the existing institutions with new norms, which more specifically define the functions of the former, or substitute the existing institutions with new ones, which used to be of informal nature. In reality, legalization of informal institutions may either be the initiative by the state-run public authorities, or may be forced or lobbied through by interest groups. There is a very typical illustration in point: the legalization in 1992 of the then widespread spontaneous privatization and the formation of the corporate management institution (Corporate Law).

The reformers had to take into consideration the viewpoints of apologists for the establishment of collectively-owned enterprises and for free distribution of the state-owned property to all levels of the population. In keeping with the Government Program of Privatization, labor collectives derived unprecedented benefits, which can be regarded as concessions to the management in return to their loyalty to the economic reforms carried out by the government. Furthermore, in order to avoid social tension in the society a privatization mechanism was developed and implemented, when vouchers were issued to each adult citizen that were to be used to purchase shares of public property being privatized via investment trusts or special auctions.

The 1990s in Russia were the time for price liberalization and the outset of privatization. No regulatory institutions were there to stand as guidelines of entrepreneurship. The arbitration courts were immature and had no experience in resolving privatization conflicts and corporate dispute settlements; coercive and administrative approaches prevailed.

Of a special importance in the evolution of economic institutions is borrowing or importing them from other countries. Thus, the import of institutions is regarded as a revolutionary version of the institutional evolution, for it presumes implementation of formal institutions that have a proven record of their efficiency to provide interactions, with the existing institutions being the last to be adopted.

In reality economic interactions occur between companies from various countries and the economic institutions 
in these countries are constantly evolving, with various formal and informal norms being exchanged and general requirements being established to the functioning of certain institutions. As a result, a sort of diffusion of the relevant norms is observed-for instance, the norms of the legitimate enterprise-that forms an integrated institutional space in the field of entrepreneurship. Hence, one can put forward examples of the Russian legislation in the field of corporate law, bankruptcy and nature management. It is worthy of note that the evolution of corporate management institutions in Germany, France and other European countries is significantly influenced by the EU legislation that experiences rather challenging corporate problems. These problems reflect a number of critical aspects addressing economic interrelations of the member states, in particular, the directives that define procedures for corporations, limited liability companies and some other types of business organizations.

Hence, in order to suppress social and economic immunity to the "genetically" foreign formal norms, it is imperative that the government show a strong political will and a substantial foreign financial support is provided [Гдан]. As a result, the exporting country so acting would keep the formation of economic institutions under control that would help to expand its political and economic influences on the importing countries, to make the economics of companies and government in the importing country information-transparent, and to reduce transaction costs of national and international companies entering the markets of the recipient countries. That leads to behavioral conflicts between entrepreneurs. As a result, one can observe a substantial disparity in the consequences of importing the European corporate management institutions into the former socialist countries, Russia and FSU countries, which differ significantly in terms of the historical path covered, their national and cultural characters and the customs of business intercourse. More or less effectively, such European countries as the Czech Republic, Slovakia, Germany, Hungary and Baltic countries have relatively easily been adopting the imported European institutions owing to their positive historical experience over the pre-socialist period some 40-50 years ago, due to their basic conditions and because of their respective national scales.

At the same time, the assessment is not so clear with regard to the import of corporate management institutions into Euro-Asian and Asian countries such as Russia, Kazakhstan, the republics of Central Asia, etc., which have considerable national and cultural differences as compared with the European countries. Peculiarly, Vietnam, Mongolia and China tend to go their separate ways to reform their economies.

\section{Results}

Over the last decades restoration of norms and institutions has been particularly prevalent in Russia and the former socialist countries. In fact, the majority of the countries have reestablished their pre-existing economic institutions of corporate management, insolvency, equity market and some others. The restoration of institutions, however, was usually of the duel nature. On the one hand, the institutional functionality was recovered; for instance, the private property and the corporate law. On the other hand, the content of norms constituting the institutional base was, in fact, borrowed from the legislations of other European countries. Therefore, a mixed version of the evolution of economic institutions was realized that combined restoration of their forms with the import of contents. Such an approach is usually justified as a result of the political choice by the local elite and as influences exerted by the governments of other countries. Efficiency of this approach is to be challenged only upon changes in the nature of the reforms caused by another (opponent) political party's coming to power, initiating reappraisal of the objectives to be gained and revising the policies and actions of the predecessors.

Regardless of the significant differences between the chosen patterns of economic performance, the processes of their adaptation to the specific conditions in the former socialist countries have faced similar problems: the criminalization of economy, the lack of information transparency on the activities of corporations, the infringements of shareholders rights, the low incentives for managers to enhance financial performances of their companies, etc. These problems have delayed the reforms and hindered their expediency in the majority of the countries.

That has evidenced the inertness of the institutional change due to the following: firstly, the prevailing economic ideology; secondly, the existing customs of business intercourse, the national and cultural peculiarities and historical traditions; and thirdly, the features of the supply, type and use of the natural resources and the geographic size of the country.

Furthermore, the imported institutions overlap with the existing-more or less efficient-institutional environment containing the specific set of norms, values, etc., which define motivation of the economic decision-makers involved. Therefore, the essence of inertness phenomenon is, on the one hand, in the relationship between the traditional and the imported norms, and, on the other hand, in the process of the economic community members' choosing the norms that they should follow. 
Choice of economic agents from the very start bears a certain contradiction: the discrepancy between the ideal behavioristic model of an entrepreneur's acting bona fide and abiding the laws and other formal norms currently in force on the one hand, and the interests of his agent and shareholders (members) on the other. Besides, the list of persons that are-directly or indirectly-interested in outcomes of the choice is not limited only by those above mentioned; and their interests may as well be in conflict. As a result, the process of decision making takes quite a lengthy period of rivalry so that certain norms of economic behavior can be affirmed. Regardless of the outcome, however, the economic community members would have to correct the already existing norm, whether they accept the new behavior pattern or reject it.

The assessment of consequences of importing economic management institutions for a recipient country becomes a challenge in its own right. Moreover, such assessment can also depend on both the specific time frame and the reference point used. One should take into account that, since the imported institutions are rather complementary to the existing institutional structure of the national economy, effectiveness of the management structure cannot be evaluated regardless of the specific arrangements and settings of other institutions.

\section{Conclusions}

Introduction of new economic institutions in Russia traditionally reflects the political influence of various European countries and the United States of America on the political power elites in the former socialist and FSU countries. At the same time, the analysis reveals that the FSU countries have traditionally been imposed on with a certain institutional model of economic performance.

Import of institutions, however, is often prone to creating chaos caused by contradictions between the institutional environment of the importing country and the institutional environment of the exporting country, with which the imported norms have genetic roots.

It is evident from past experience that as the formal institutions under the auspices of the organs of government as the informal norms-which are independently accepted by the market participants or by business groups-, both can be imported.

The efficiency assessment of economic institutional novations cannot be made one-dimensionally, for it is measured against at least two scales: on the one hand, the correspondence to the objectives and to the interests of the national development in the specific recipient country, and, on the other hand, the attainment of objectives by the exporting country, for instance, the formation of "parent state-raw material source colony" relationships.

\section{Acknowledgements}

This paper prepared at the financial support of Ministry of Education and Science of Russian Federation (research project \# 12-C-7-1007).

\section{References}

Aron, J. (2000). Growth and institutions: A review of the evidence. World Bank Research Observer, 15(1), 99-135. http://dx.doi.org/10.1093/wbro/15.1.99

Ben-Ner, A., \& Putterman, L. (2000). On some implications of evolutionary psychology for the study of preferences and institutions. Journal of Economic Behavior and Organization, 43(1), 91-99. http://dx.doi. org/10.1016/S0167-2681(00)00110-4

Bergstrom, T. C. (2002). Evolution of social behavior: Individual and group selection. Journal of Economic Perspectives, 16(2), 67-88. http://dx.doi.org/10.1257/0895330027265

Bortolotti, B., Siniscalco, D., \& Fantini, M. (2000). Privatization and Institutions: A Cross Country Analysis. CESifo Working Paper, No. 375. Munich.

Caravale, G. (1995). Economic theory, institutions, and economic policy. Atlantic Economic Journal, 23(4), 241-247. http://dx.doi.org/10.1007/BF02298760

Chakravarti, A. (2012). Institutions, economic performance and the visible hand: Theory and evidence. Edward Elgar Publishing,

Chang, H. J. (1998). The Role of Institutions in Asian Development. Asian Development Review, 16(2), 64-95.

Chang, H. J. (2002). Breaking the mould: An institutionalist political economy alternative to the neo-liberal theory of the market and the state. Cambridge Journal of Economics, 26(5), 539-559. http://dx.doi.org/10. $1093 / \mathrm{cje} / 26.5 .539$

Chang, H. J. (2011). Institutions and economic development: Theory, policy and history. Journal of Institutional 
Economics, 7(4), 473-498. http://dx.doi.org/10.1017/S1744137410000378

Chang, H. J. (Ed.) (2007). Institutional Change and Economic Development (pp. 17-33). Tokyo: United Nations University Press, and London: Anthem Press.

Che, J., \& Qian, Y. (1998). Institutional environment, community government, and corporate governance: Understanding China's township-village enterprises. Journal of Law, Economics, and Organization, 14(1), 1-2. http://dx.doi.org/10.1093/oxfordjournals.jleo.a023392

Cheng, T. J., Haggard, S., \& Kang, D. (1998). Institutions and growth in Korea and Taiwan: The bureaucracy. Journal of Development Studies, 34(6), 87-111. http://dx.doi.org/10.1080/00220389808422547

Cimoli, M., Dosi, G., \& Stiglitz, J. (2009). Industrial Policy and Development: The Political Economy of Capabilities Accumulation. Oxford: Oxford University Press. http://dx.doi.org/10.1093/acprof:oso/97801 99235261.001.0001

Dorward, A., Kydd, J., Morrison, J., \& Poulton, C. (2005). Institutions, markets and economic coordination: Linking development policy to theory and praxis. Development and Change, 36(1), 1-25. http://dx.doi.org/ 10.1111/j.0012-155X.2005.00400.x

Dorward, A., Poole, N., Morrison, J., Kydd, J., \& Urey, I. (2003). Markets, institutions and technology: Missing links in livelihoods analysis. Development Policy Review, 21(3), 319-332. http://dx.doi.org/10.1111/14677679.00213

Durkheim, E. (1993). The Division of Labour in Society. The Free Press, New York.

Eerkens, J. W. (2004). Privatization, small-seed intensification, and the origins of pottery in the western great basin. American Antiquity, 69(4), 653-670. http://dx.doi.org/10.2307/4128442

Engerman, S. L., \& Sokoloff, K. L. (2005). The evolution of suffrage institutions in the New World. Journal of Economic History, 65(4), 891-921. http://dx.doi.org/10.1017/S0022050705000343

Engerman, S. L., \& Sokoloff, K. L. (2008). Debating the role of institutions in political and economic development: Theory, history, and findings. Annual Review of Political Science, 11, 119-135. http://dx.doi.org/10.1146/annurev.polisci.11.120406.135217

Gehlbach, S., \& Keefer, P. (2011). Investment without democracy: Ruling-party institutionalization and credible commitment in autocracies. Journal of Comparative Economics, 39(2), 123-139. http://dx.doi.org/10.1016 /j.jce.2011.04.002

Glaeser, E. L., La Porta, R., Lopez-de-Silanes, F., \& Shleifer, A. (2004). Do institutions cause growth? Journal of Economic Growth, 9(3), 271-303. http://dx.doi.org/10.1023/B:JOEG.0000038933.16398.ed

Haggard, S., \& Chung-In, M. (1989). Institutions and economic policy: Theory and a Korean case study. World Politics, 42(2), 210-237. http://dx.doi.org/10.2307/2010464

Haggard, S., \& Zheng, Y. (2013). Institutional innovation and investment in Taiwan: The micro-foundations of the developmental state. Business and Politics, 15(4), 435-446. http://dx.doi.org/10.1515/bap-2012-0010

High, J. (2009). Entrepreneurship and economic growth: The theory of emergent institutions. Quarterly Journal of Austrian Economics, 12(3), 3-36.

Hodgson, G. (2009). On the institutional foundations of law: The insufficiency of custom and private ordering. Journal of Economic Issues, 43(1), 143-166. http://dx.doi.org/10.2753/JEI0021-3624430107

Holcombe, R. G. (1998). Entrepreneurship and economic growth. The Quarterly Journal of Austrian Economics, l(2), 45-62. http://dx.doi.org/10.1007/s12113-998-1008-1

Holcombe, R. G. (2003). The origins of entrepreneurial opportunities. Review of Austrian Economics, 16(1), 25-43. http://dx.doi.org/10.1023/A:1022953123111

Kuran, T. (2004). Why the Middle East is economically underdeveloped: Historical mechanisms of institutional stagnation. Journal of Economic Perspectives, 18(3), 71-90. http://dx.doi.org/10.1257/0895330042162421

Mingaleva, Z., \& Gataullina, A. (2012). Structural modernization of economy and aspects of economic security of territory. Middle East Journal of Scientific Research, 12(11), 1535-1540.

Mingaleva, Z., \& Mirskikh, I. (2009). The Problems of Legal Regulation of Intellectual Property Rights in innovation activities in Russia (Institutional approach). World Academy of Science, Engineering and Technology, 29, 464-476. 
Mingaleva, Z., \& Mirskikh, I. (2013). Small innovative enterprise: The problems of protection of commercial confidential information and know-how. Middle East Journal of Scientific Research, 13(SPLISSUE), 97-101.

Mingaleva, Z., Gayfutdinova, O., \& Podgornova, E. (2009). Forming of institutional mechanism of region's innovative development. World Academy of Science, Engineering and Technology, 58, 1041-1051.

Mingaleva, Zh., \& Mirskikh, I. (2014). The main institutional instruments of intellectual property protection. Life Science Journal, 11(12s), 170-173.

Nabli, M. K., \& Nugent, J. B. (1989). The New Institutional Economics and its applicability to development. World Development, 17(9), 1333-1347. http://dx.doi.org/10.1016/0305-750X(89)90076-4

North, D. C. (1990). Institutions, institutional change and economic performance. New York: Cambridge University Press. http://dx.doi.org/10.1017/CBO9780511808678

North, D. C. (1995). The New Institutional Economics and Third World Development, 17-26.

Ostrom, E. (1990). Governing the commons: the evolution of institutions for collective action, 280.

Ostrom, E. (2007). Challenges and growth: The development of the interdisciplinary field of institutional analysis. Journal of Institutional Economics, 3(3), 239-264. http://dx.doi.org/10.1017/S1744137407000719

Pejovich, S. (1972). The Economics of Legal Relationships, 37-52.

Perotti, E. C. (1995). Credible privatization. American Economic Review, 85(4), 847-859.

Saussier, S., Staropoli, C., \& Yvrande-Billon, A. (2009). Public-private agreements, institutions, and competition: When economic theory meets facts. Review of Industrial Organization, 35(1-2), 1-18. http://dx.doi.org/10. 1007/s11151-009-9226-Z

Shelomentsev, A. (2007). Specifics of evolution of economic institutions in Russia. Corporate Moral Responsibility and Social Integrity. Gdansk University of Technology. Institute of Economics, 89-93.

Spiller, P. T. (1996). Institutions and commitment. Industrial and Corporate Change, 5, 421-452. http://dx.doi.org/10.1093/icc/5.2.421

Spiller, P. T. (2008). An institutional theory of public contracts: Regulatory implications. NBER Working. Paper No. 14152.

Stein, H. (1994). Theories of institutions and economic reform in Africa. World Development, 22(12), 1833-1849. http://dx.doi.org/10.1016/0305-750X(94)90177-5

Stein, H. (2008). Beyond the World Bank Agenda-An Institutional Approach to Development. Chicago: University of Chicago Press. http://dx.doi.org/10.7208/chicago/9780226771656.001.0001

Streeck, W. (1992). Social Institutions and Economic Performance. London: Sage Publications.

Udry, C. (2003). Fieldwork, economic theory, and research on institutions in developing countries. American Economic Review, 93(2), 107-111. http://dx.doi.org/10.1257/000282803321946895

Van den Bergh, J. C. J., \& Stagl, S. (2003). Co-evolution of economic behaviour and institutions: Towards a theory of institutional change. Journal of Evolutionary Economics, 13(3), 289-317. http://dx.doi.org/10. 1007/s00191-003-0158-8

\section{Copyrights}

Copyright for this article is retained by the author(s), with first publication rights granted to the journal.

This is an open-access article distributed under the terms and conditions of the Creative Commons Attribution license (http://creativecommons.org/licenses/by/3.0/). 